\title{
Chapter 5. \\ The Equine Business: The Spectacular Growth of a new Equine segment market in France
}

\author{
Gwenaëlle Grefe \\ Associate Professor, Management \\ Université d'Angers, ESTHUA \\ GRANEM \\ Sylvine Pickel-Chevalier \\ Associate Professor, Geographer \\ University of Angers, ESTHUA \\ ESO (Espaces et Sociétés), CNRS UMR 6590
}

\begin{abstract}
A social revolution in riding has created incredible growth in the equine-product market. This new equine economy is, in fact, characterized by the range of activities available (32 riding styles are listed by the $\mathrm{FFE}^{1}$ ), by riders' needs (equipment for both riders and their horses including fences, water troughs, horse-boxes etc.), by product ranges (from entry-level to luxury goods), but also by fashion which, thanks to the profile of today's horse-riders (predominantly female and young) has become a key part of the market. This enthusiasm has led to the development of businesses, the majority of which have appeared in the last thirty years in France (Antarès, CWD, GPA, Cheval Shop, EquipHorse, Fautras etc.). While they have become key references in the sector, and account for nearly half of all jobs related to the equine sector in France (38,900 agricultural jobs compared to 32,800 non-agricultural jobs including business, veterinary care, farriers and public bodies - IFCE ${ }^{2}, 2011$ ), their characteristics remain largely unexplored.
\end{abstract}

Key words: Equine, business, growth, market, innovation

\section{Introduction}

Since the 1960s and 70s horse riding has become part of consumer and leisure society that triumph (Corbin, 2001; Dumazedier, 1962; MIT, 2005), to the point where it is now a commodity. The logic of taking riding-lessons, and as such, being initiated in the art of an elite culture (Roche, 2008; Franchet d'Espérey, 2011), has been surpassed by that of hedonism (Digard, 2009; 2004). The French Equestrian Federation had 145,071 members in 1984, 434,980 in 2000 and the number now stands at $689044(2014)^{3}$, with an estimate of around 2.2 million riders overall, including outdoor and casual riders who are not all clubmembers. The FFE is today the third-largest sports federation in France and the first femaledominated (Defrance, 2011; Tourre-Malen, 2006). However, this growth has been accompanied by a profound change in the way people ride (Grefe \& Pickel-Chevalier, 2014;

\footnotetext{
${ }^{1}$ FFE : Equestrian French Federation.

${ }^{2}$ IFCE : French Institute for Horse and Horse Riding (Jez, 2013).

${ }^{3}$ http://www.ffe.com/journaliste/Publications/Statistiques.
} 
Chevalier. and Dussart, 2002) coming from changes in rider profiles and their expectations. Seventy pourcent of French riders in 2014 were aged 18 or younger and 55\% were 14 or under. In addition, $82 \%$ of all these riders were female ${ }^{4}$. Riding has also become part of a process of relative social diffusion concerning mostly the middle and upper-middle classes, as well as the upper classes (Terret, 2007; Tourre-Malen, 2009). This change of profiles and the fact that riding has moved into today's consumer society has created a diversification of needs and supplier to meet those needs. While clubs, which are anxious to retain their customers (Chevalier, 1998 ; Grefe \& Pickel-Chevalier, 2014), strive to increase the range of activities on offer (show-jumping, dressage and cross-country, but also pony games, fun games, voltige, horse-ball, outdoor-riding, western-style riding etc.), traditional practices are being replaced by a "new baroque equestrian culture", meaning very heterogeneous practices (Digard, 2009, p.16).

This social revolution in riding has created an incredible growth in the equine-product market. This new equine economy is, in fact, characterized by the range of activities available (32 riding styles are listed by the FFE), by riders' needs (equipment for both riders and their horses including fences, water troughs, horse-boxes etc.), by product ranges (from entry-level to luxury goods), but also fashion which thanks to the profile of today's horse-riders, predominantly female and young, has become a key part of the market. This enthusiasm has led to the development of businesses, the majority of which have appeared in the last thirty years in France (Antarès, CWD, GPA, Cheval Shop, EquipHorse, Fautras etc.). While they have become key actors in the sector, and account for nearly half of all jobs related to the equine sector in France (38,900 agricultural jobs compared to 32,800 non-agricultural jobs representing business, veterinary care, farriers and public bodies - IFCE, 2011), their characteristics remain largely unexplored.

The purpose of this study is to better understand those equine businesses. How they are characterized and where they are located across France? How do they respond to today's unprecedented diversification of demand, which has become much larger but also somewhat volatile? How do they also fit into a market characterized by globalization and increased competition? Do they borrow entrepreneurial logic from other sectors of the economy when setting their objectives and activities (searching for profitability and performance, adaptability or innovation), or do they manage to define a corporate culture which is specific to the equine industry by syncretism ${ }^{5}$ ? Indeed, can equine businesses invent their own logic between global entrepreneurial methods and particularities of equestrian needs and traditions? If the latter is true, does it allow new jobs requiring specific professional training to emerge, and which are unique to the equine sector?

\section{Methodology}

To answer these questions, we focus primarily on the growth of this new economy and its distribution across France. We determine which types of business characterize this highly specialized emerging sector, and where they are located around the country. We then focus on an analysis of how they have adapted to the equine sector in a market economy. Finally, we analyse the process by which those involved in the sector improve their professionalism.

\footnotetext{
${ }^{4}$ http://www.ffe.com/journaliste/Publications/Statistiques.

${ }^{5}$ Synthesis of two or several cultural beliefs or practices from different origin, giving rise to new cultural forms.
} 
Our methodology is be based on:

1) A study of businesses selling equine products, listed by the IFCE (French Institute for Horse and Riding) and the Annuaire du Cheval. The latter is a private directory published by a specialist magazine called L'Eperon. To be listed in this directory companies need to pay a fee. Nevertheless, its reputation in France has led the vast majority of companies, both large and small, to sign up. This approach will allow us to identify the different types of companies already in the market (small-businesses, chains, and large groups), their areas of activity and their distribution across the country.

2) An interpretative analysis of interviews with the managers of 12 companies specializing in the market for equine products in order to understand, by combining and comparing their answers, what growth and progress strategies are employed by companies representative of the market.

3) The study of how the Professional Degree in Marketing of Equine Products, at the University of Angers (ESTHUA ${ }^{6}$ ) on the Saumur campus, is run. This professional degree is unique in France in its focus and receives offers of placements and is visited by companies from around France looking for to recruit students. These graduates are highly employable. The analysis of how this training is run - the criteria for joining the course, the organization of its content, its statistics, its employment success rates, the sectors concerned and the location of these jobs - will allow us to study the emergence of a new professional profile specialized in the marketing and sale of equine products .

\section{An abundance of supply in response to changes in demand}

The horse riding market had deeply changed, according to the recent evolution of the practices and representations of horse, that we called the "contemporary revolution" (PickelChevalier \& Grefe, 2014). The sector is marked by a combination of social processes linking distribution, rejuvenation, feminization, anthropomorphism and hedonism (Digard, 2009) .This phenomenon allowed the equine products and services to explode. The Annuaire du Cheval 2013 listed 2,470 French and foreign companies present in the country. They are mostly young companies (mainly founded since the 1990s) and with varied structures. They are dominated by a plethora of small family-run businesses, punctuated by a few chains (Padd and Horsewood which merged early this decade, Horse Shop) and groups with a large market presence (Decathlon, Go Sport, Terres et Eaux).

These 2,470 listed companies include manufacturers, wholesalers and distributors, which are unequally divided between the following nine sectors of the industry: tack and saddlery (representing 730 companies, so $30 \%$ of the market); transport, infrastructure, food and health, but also equestrian tourism agencies, blacksmiths (producers of horse-shoes), firms specializing in consulting and services, and the arts and media including the specialist press.

While the market looks like it is a niche, given the fact that less than $4 \%$ of the French population regularly or occasionally go riding ( 2.2 million riders out of a total population of 65 million - INSEE, 2013), it has a structure which seems to be leading to a metamarket (Kotler, 2009). By metamarket, we mean a market which gather multiple sub-markets such as

\footnotetext{
${ }^{6}$ Esthua: Faculty of Tourism and Hospitality of the University of Angers.
} 
transportation, food, health, tourism, etc. In fact, this net of apparently heterogeneous markets is characterized by a marketing relationship providing an ample supply of products linked to the initial purchase, that of a horse or hours of riding-lessons (Lambin \& Moerloose, 2012). The activity of riding, but more importantly the purchase of a horse leads to an increase in need of equine products, today partly created by specialist companies using the model of mass distribution by combining the phenomena of fashion with an emotional tendency for anthropomorphism (for horses, but also for riders' equipment).

A specific analysis of the sector of tack and saddlery (the distributors of which may also be the manufacturers), which represents one third of all the equine product firms, allows us to observe trends in the market. The first observation to make is that if the large specialist distributors seem low in number (there are really only three players in the market, the first of which is Decathlon, the second being Go Sport, with Terre et Eaux coming third) they represent $52 \%$ of all tack shops (with 380 outlets). As such, even if their reputation is a subject of debate, such specialist shops represent just over half of tack sales outlets in France. We can't say that they behave like oligopolists, since almost half of the market is composed of small and independent companies. Beside, those large distributors are more specialized into entry-level products for leisure, whereas high-end products for competition are sold into smaller specialized shops. They testify about the inscription of riding growth into the more global development of sport of nature (Bessy\&Mouton, 2004; Pickel-Chevalier, 2015).

An analysis of the location of tack shops in mainland France reveals that the whole country is covered, with every area having at least one saddlery. This reflects an equestrian activity spread across the country which nevertheless varies greatly from one region to the next. In fact the number of tack shops per area varies from 1 to 26 (Figure 1).

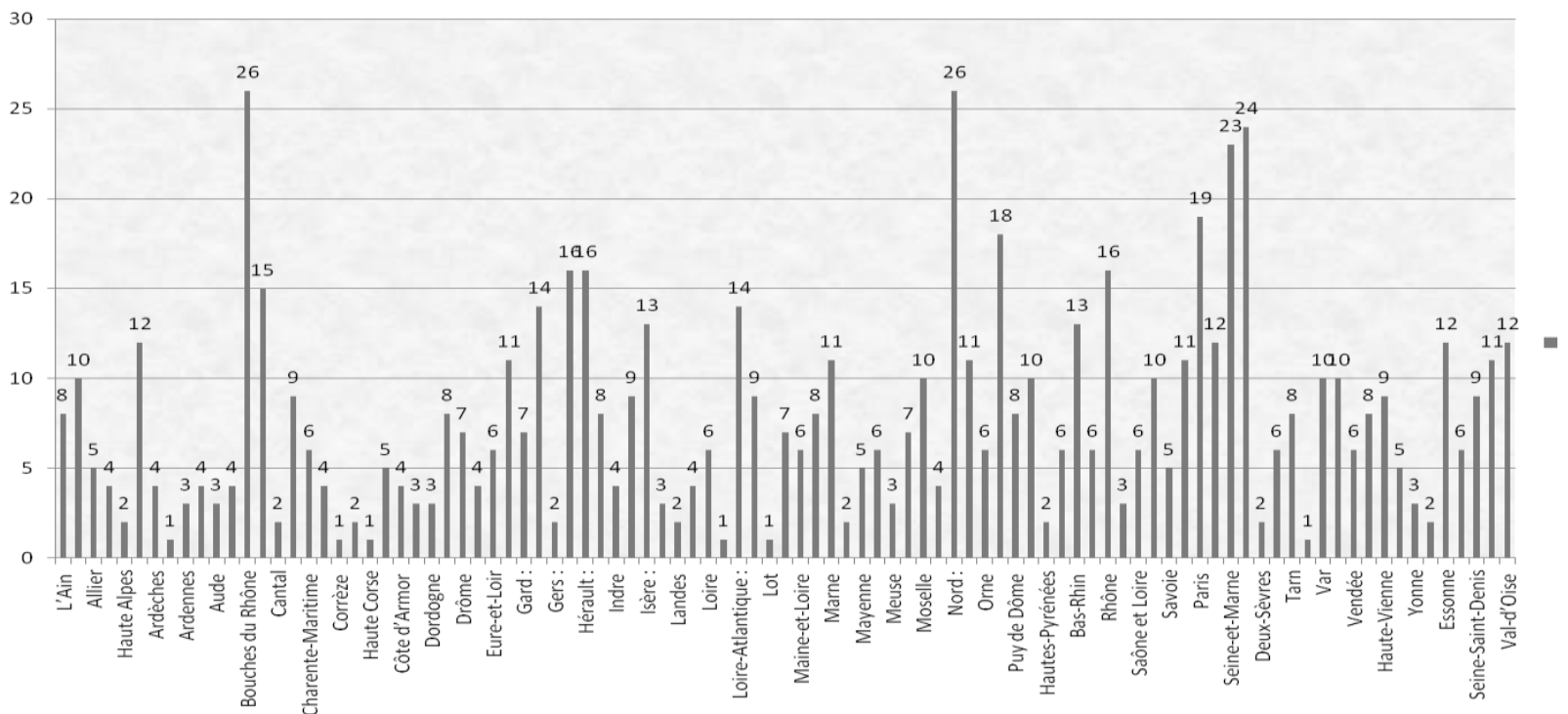

Figure 1. Distribution of tack shops per area in France (Source: l'Annuaire du Cheval 2013, Design by S.Pickel-Chevalier).

Their geographical locations show important similarities with the locations of ridingcentres, which themselves correspond to departments ${ }^{7}$ of high population density (IFCE,

\footnotetext{
${ }^{7}$ France is made up of 95 counties called « departements ».
} 
2011). Like riding-clubs and schools, the tack shops are therefore as close as possible to areas with a high concentration of riders, in the major cities (Grefe \& Pickel-Chevalier, 2014). As such, only four departments of France have between 23 and 26 tack shops, namely the Bouches-du-Rhône in the South East (26 stores), the North (26 stores), the Yvelines (24 stores) and the Seine et Marne (23 stores) in the Paris region. The eight departments making up the Ile-de-France have a total of 116 outlets which represents $16 \%$ of all the whole French market. This high concentration corresponds to the structure of the French population: the Ile-deFrance has 11.8 million people out of a national total of 65 million which is equivalent to $18 \%$ - INSEE, 2013. Riding is now an urban activity (IFCE, 2011; Grefe \& Pickel-Chevalier, 2014) and tack shops take advantage of both an abundance of riders and a greater level of purchasing power than the national average. The Bouches-du-Rhône in the south of France (in the Provence-Alpes-Côte d'Azur region) is in the same situation as it is the third most populous area in France with nearly 2 million people, more than 850,000 of whom live in the city of Marseille (INSEE, 2013). The population of the Bouches-du-Rhône also has a higher income level than the national average.

This high purchasing power is not however present in the area which comes third in terms of the number tack shops, namely the north. However, it is the most populous region in France with over 2.5 million inhabitants (INSEE, 2013) of which more than 220,000 live in Lille. The high density of tack shops reflects the historical importance of the sporting massmarket retailing sector, due to the founding of the Decathlon chain in 1976 in the region. Today, the company, which has stores in 18 countries worldwide, has a high local concentration with 11 Decathlon stores distributing tack equipment and its own sub-brand, Fouganza, just for equestrian products. The area also has 3 Go Sport, 3 Padds and 3 Horsewood shops. Large stores therefore dominate the local market where the population does not need to have high purchasing power due to more competitive pricing.

Finally, the areas with the fewest number of tack shops corresponds roughly to the least populated regions in France, extending from the South (Ariège), South-Center (Tarn-etGaronne, Lot, Haute-Loire, Corrèze) to the North-East (Ardennes) (Figure 2).

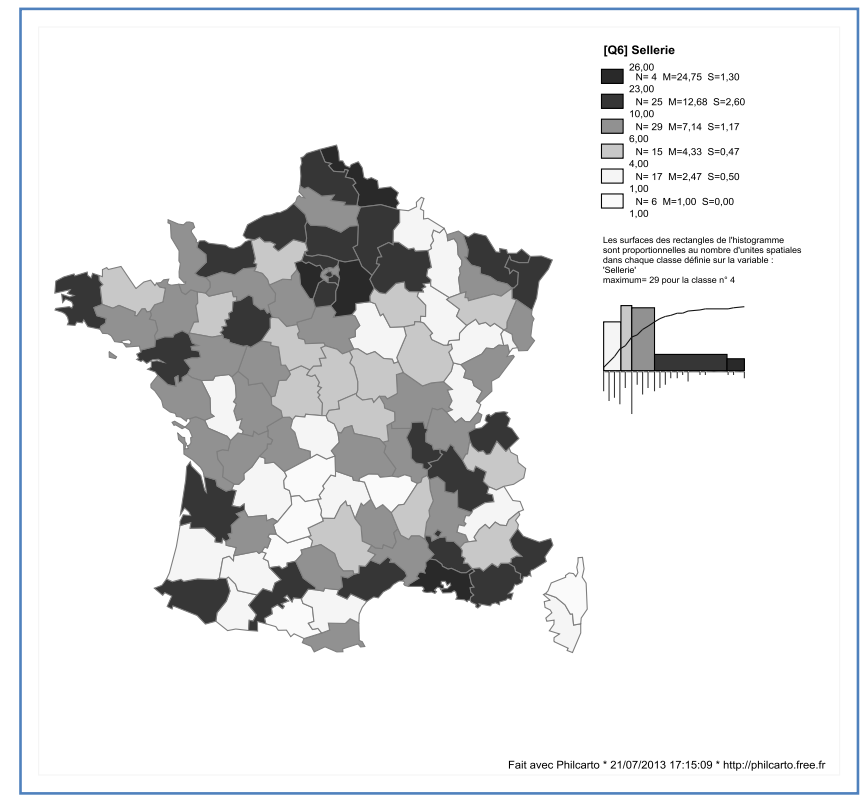


Figure 2. The geographical location of tack shops (distributors) in mainland France: a spread which corresponds to population densities, urbanisation and purchasing power.

Design: S. Pickel-Chevalier, 2013.

As such, the location of tack shops in mainland France is more linked to population density, urbanization levels and the purchasing power of the population than to riding traditions or breeding centres. So, the two areas which are the most heavily involved in the equestrian agricultural sector (breeding, racing, equestrian sports), the Orne (headquarters of the National Stud Farm) and Maine-et-Loire (headquarters of the IFCE and Cadre Noir de Saumur) only have six outlets each, of which the majority are large specialist chain-stores.

This location of tack shops, determined by the location of their customers, thus reflects the changing pattern of equestrian activities, moving from traditional agricultural and rural bases to become a leisure pursuit favoured by the relatively wealthy urban population.

It is now important to understand how companies have managed to meet the demands of the new market besides their policy of geographical proximity.

\section{Adapting the trade in equine products, involving the market economy}

To analyze the sales and marketing strategies which have allowed companies in the sector to adapt to the 'revolution' of horse riding in France, marked by the combination of distribution, rejuvenation, feminization, anthropomorphism and hedonism (Pickel-Chevalier \& Grefe, 2014), we conducted a survey of twelve companies which display significant dynamism in their diversified activities. Between January 2012 and January 2014, we interviewed:

- Arnaud Lièvre, sales director of the up-market tack specialist Butet. Based in Saumur, this saddlery founded by Frédéric Butet in 1987 was taken over in 2012 by Arnaud Butet and Olivier Perdrix. The Butet saddlery represents French tradition, specializing in equipment for sport competitions, more especially show jumping. Its influence is international. Butet saddles are selected specifically by lots of riders at the Cadre Noir de Saumur. The company employed 29 people in 2012.

- Noémie Renard, marketing director of the up-market tack specialist $\mathrm{CWD}^{8}$. Founded in 1998 in Nontron (Périgord) by Laurent Duray, the CWD saddlery specializes in innovation and research into high performance for those involved in competitions. It is the worldwide leader in the sale of up-market saddles and is a supplier to a number of world champions, such as Kevin Staut. It produces 3,500 saddles each year, half of which are sold for export. The company is also known for its very aggressive marketing strategy.

- Gaston Mercier, director and founder of the up-market tack specialist Gaston Mercier. Founded in 1998 in Aveyron by Gaston Mercier, a former European (1987-1989) and French (1988) champion in endurance riding, the saddlery is famous for making upmarket saddles for endurance and outdoor riding combining traditional leatherworking and innovations (such as double offset stirrups - Innovation Award for 2013 at the Salon du Cheval de Paris). It has national and international representation. His son, Manuel Mercier, joined the company in 2008. The company therefore remains a family business and had fifteen employees in 2013.

\footnotetext{
${ }^{8} \mathrm{CWD}$ is the name of the company.
} 
- Albert Joel, founder and director of the boot-makers Botterie Saumur Albert Joel. Founded in 1989 in Saumur (Maine et Loire), the company specializes in up-market made-to-measure riding boots, considered a luxury product ( $€ 1,500$ to $€ 4,000$ euros per pair). The company uses traditional French leather working techniques and employs four people. It sells its products through national and international outlets.

- Carlos Biclet, director of Cheval Shop. Founded in 2005 in Loire-Atlantique by Carlos Biclet and his wife Corinne Guesdon, Cheval Shop specializes in equipment for horses and riders in the mid-range market, with many unique products. The company which employed 23 people in 2013 has five stores (Nantes, Ile-de-France, le Mans, Haras de Jardy) and a soon to open shop in Lyon. The company is the third biggest tack shop (for horse and rider equipment) in France in terms of sales after Padd and Horsewood which have now merged. Cheval Shop also develops its own products (Time Riders). Their market is mostly in France, but the managers are looking to expand into Russia and Asia.

- Jean-Philippe Lucas, sales manager of the GPA Sport group. Founded in 1972, GPA helmets (Groupement pour la Protection Automobile) initially made protective headwear for Formula 1 car racing (famously worn by Alain Prost and Nelson Piquet) before their inventor Michet Finquel decided to transfer this technology to riding hats. GPA Sport was founded in 1998 (with its headquarters in Toulon). GPA riding-hats are now considered to be the world's leading equipment worn by champions around the world in every equestrian discipline, including racing.

- Valentin Vielledent, director and founder of the company Poney Matériel. Founded in 2003 in Valenciennes (North), this company specializes in pony games equipment for horses and riders. It is the only company licensed to provide material for pony games competitions in clubs in France. It is known for having created, in addition to specialized equipment, a new fashion in equestrian clothing by borrowing styles from team sports.

- Hervé Hoffer, director of the company AJC Nature selling equine care products. Founded in 2005 in Alsace by Mr. Hoffer and his wife, this family business specializes in natural care products for the well-being of horses (natural worm treatments, therapeutic care for rheumatism, emphysema, etc.) which are sold in the mid-range price bracket. The company has three employees and sells its products via mail order throughout France.

- Christophe Lesourd, director of the specialist travel agency Cavalier du Monde. Founded in 2005 in the Paris area, the company sells equestrian holidays on five continents. This is the newest and smallest - with just 2 employees - of the main travel agencies specializing in equestrian tourism in France (Rando-Cheval, Cheval d'Aventure and Caval and Go), and is known for its 'responsible' attitude, having been $\mathrm{ATR}^{9}$ certified.

- Sandra Arderius, personal assistant to the editor of the specialist industry journal L'Eperon. Established in 1936, L'Eperon is one of the oldest companies in the sector. It has an excellent reputation and is considered the reference for breeding and competition in France. The company also owns the website www.cavadeos.com and the specialist bookshop Cavalivres. It employed 25 people in 2013.

\footnotetext{
${ }^{9}$ «Agir pour un Tourisme Responsable» is a French label of sustainable tourism: «Act for Responsible Tourism ». It is an AFNOR certification based on social, cultural and environmental norms, but also politic of natural resources preservation.
} 
- Claude Lux, journalist and technical director of Randonner à Cheval, the only French magazine specializing in outdoor riding. The magazine was founded in 2005 by JeanMichel Millecamps, and is sold in newsagents and via subscription. Claude Lux is also the author of around thirty technical books on outdoor horse-riding, as well as novels for children on the subject of horses.

- Jean-Léonard Fautras, son of the founder and sales director of the family business Van Fautras. Founded by Jean-Luc and Marie-Noelle Fautras in 1992, the company specializes in creating horse-boxes, made in France, which are known for their innovative style. They hold seven European patents and have won five trophies for innovation awards at the Salon du Cheval. The company employs 120 people at their production site in the department of Dordogne.

The companies were selected to represent varied dynamic sectors of the industry (saddlers, tack shops, boot makers, the specialist press, equestrian tourism, equipment, care products, riding hats, and horse boxes). They have varied levels of success, from retailers which dominate the market (CWD, Butet, Cheval Shop etc.) to newly emerging companies (AJC Nature, Cavalier du Monde). Their positioning also highlights the diversity of the sector, from the up-market (Butet, CWD, bottier Albert Joël, GPA, Gaston Mercier etc.) to mid-range products (Cheval Shop, Poney Matériel, AJC nature, Randonnée à Cheval.).

Semi-organised interviews were conducted between January 2012 and January 2014, except for an interview with Jean-Léonard Fautras in November 2009. These professionals have close personal links with the industry, either as enthusiastic riders themselves or married to highly-skilled riders (Frédéric Butet, Albert Joël). Only the two gentlemen who took over the Butet tack shop business (Arnaud Lièvres and Olivier Pedrix) come from other sectors but they have now also started riding.

\section{Results}

The initial findings, as to what these people feel is the current state of the equine business, all show they believe the market is maturing no matter what activity is involved. As such, "Horse-riding around the world has gained significant public awareness and so the services on offer have developed accordingly, and the number of outlets too. This market has matured," says C. Lesourd, director of the travel agency Cavalier du Monde. This maturation has also led to a more professional market, characterized by increased competition. "Since my arrival, I have noticed a fairly intense competitive activity mainly driven by aggressive marketing and pricing policies," explained A. Lièvres. This trend is of course reinforced by the financial crisis which all professionals are subject to, but has not suffered from heavy losses.

The maturation of the market is also illustrated by a better-informed customer, thanks to the many media outlets available (press, internet etc.), but still remains under the influence of opinion makers, such as instructors champions and of course media. Fashion is therefore the new factor, completely upsetting the market by responding to the innovative demands of young, female customers. A combination of colours, rounded shapes, aesthetics and a fickle trend' has completely upset a market once dominated by techniques and an undeniable tradition of austerity. As such, A. Lièvre says, "Amateur customers seem be much more under the influence of marketing than technicality itself, while the foreign market is more alert to quality and high end products from France." Carlos Biclet, who has well-understood this 
evolution and incorporated it into his products says, "I can already tell you that next spring's fashion will be green!"

To meet these new market characteristics, the companies surveyed are developing business strategies which, aside from their specificities in terms of products and positioning, are converging on a common policy based on the following elements:

a) Diversification of products and product ranges to fit in with social differentiation. As such, the tack shop Cheval Shop has increased its mid- to high-range products by importing brands from Germany and the United Kingdom which were unknown in the French market place a decade ago. The purpose was to create interest and stand out in the market by offering various stylish products not found in other tack shops. This desire to develop ranges and types of products, is particularly evident in large chain stores such as Decathlon which offers 370 products for horse-riders, 231 products for training horses and 395 products for horses at rest.

The Padd website offers 12,000 references covering all areas of horse-riding. Even companies recognized as market-leaders, such as L'Eperon, are today looking to diversify with the acquisition of the journal Sports Equestres targeting younger riders involved in competitions, but also by acquiring www.cavadeos.com and cavalivres aimed at the general public. The majority of businesses are preoccupied with offering the best value for money, helped by good market knowledge via the media (internet), but also uncertainty over the perseverance of riders. Riding in France is characterized by a high rate of people abandoning the sport, with an average of two thirds loyal riders and one third new-comers each year (FFE, 2012). The average time these new-comers ride for, before giving up, is one year and most of them are children (Grefe \& Pickel-Chevalier, 2014) so parents are reluctant to invest large sums of money upfront.

b) Identification and accessibility in this competitive market, including:

- Positioning: Companies choosing the high end of the market have a constant priority to maintain their position by insisting on French-made products. Their positioning is based on the recognition of certification and in particular that of a 'Living Heritage Company' already acquired by tack shops such as Butet, Hermès, Gaston Mercier of the boot-maker Albert Joël. The certification celebrates local production based around the preservation of traditional know-how. New types of certification are starting to appear such as 'Made in France', which particularly concerns Butet, or other more local versions such as 'Made in Aveyron' for the Gaston Mercier tack shop.

- Ethics, also using a policy of social certification (the ATER certification - working for responsible tourism -- acquired by Cavalier du Monde; or 'Made in France' proving that jobs are being created in the country supported) or with an ecological objective such as 'organic produce' developed by AJC Nature.

- Innovation which today concerns many companies in the sector. Fautras horse-boxes stand out because of its continuous innovations (including horse-boxes with U.S.-style doors, horse-boxes with diagonal stalls, horse-boxes for 3 and 4 animals). These innovations often come about as a result of technology transferred from more creative sectors of industry (automobiles, cycling, and running). In the same way, Michel Finquel imported technology he had invented for Formula 1 drivers and incorporated it into riding-hats "in order to provide the same level of safety for his young daughter when out riding" explains Jean-Philippe Lucas. Springer Stirrups, meanwhile, introduced the technology of clip-in pedals, very popular in 
cycling, to their stirrups. Even companies which claim to be traditional are opening up to innovation so as to retain their attractive up-market position. As such, Gaston Mercier leather saddles have added an innovative system of double offset stirrups. Frédéric Butet created the Practice saddle with revolutionary ergonomics. Without saddle-flaps it helps with training and riding-development by promoting a better sitting-position and closer contact with the horse.

The search for performance and innovation which today characterizes the sector needs to include these three marketing factors which now dominate consumer society. The tack shop CWD focuses much of its communication on this aim. It is based on the combination of a search for comfort and ergonomics to which riders are sensitive when motivated by pleasure (lighter and more comfortable clothing and leather which is easier to clean), but also a need for safety. The fantasy of 'zero risk' and new regulations are pushing brands to develop stronger, safer products. GPA riding-hats have been awarded certification at both European (CE) ${ }^{10}$ and U.S. (ASTM; SEI) ${ }^{11}$ levels to provide an unprecedented level of safety for the rider by combining carbon, textalium, aluminium and lorica horse-armour. In addition, the products must also meet expectations in terms of design and fashion which concern the entry level Decathlon range as well as up-market models.

The company GPA Sport has managed to produce a very safe riding-hat which is relatively large, at the risk of turning away female customer, but which is a fashion accessory and an indicator of social standing despite costing between 400 and 700 euros. For this positioning, wearing a GPA riding-hat, just like riding with a Butet or CWD saddle and or Albert Joel boots, gives riders sense of belonging to a group - a sort of 'tribalism' (Maffessoli, 2010)- which is very strong in the equestrian world. "My name hardly ever appears on my boots. The brand is represented by a simple stamped logo, but those who wear Joel Albert boots recognize them immediately," confided Joel Albert. These up-market boots, like any luxury object (Rolex, Hermès), need to be discreet and are an outward sign of wealth only shared by those in the 'community'.

c) The logics of import-export. In a market which has become globalised, equine businesses, although largely dominated by a network of small and medium-sized businesses, all develop international relations. This is a sales strategy that works especially well for highend products playing on an idea of luxury (Hermès, Butet, CWD, GPA). Nevertheless, companies specializing in mid-range products also hope to conquer the markets in emerging economies in which riding is becoming popular, like Asia (Cheval Shop). In fact, even if they are not all able to sell their products abroad, companies in the equine industry are almost always involved in the import of materials or products because of the logics of companyrelocation, which still continues, despite the willingness of some companies to move back to France.

d) The integration of the important trends of feminization and anthropomorphism.

Feminization, expressed mainly from the importance of fashion in the sector, has led directly to a transformation and diversification of products. While clothing was cut along strictly masculine lines until the 1990s (i.e. the domination of the 'Barbour' straight cut), by the millennium there was a profusion of more feminine accessories. Trousers, shirts and

\footnotetext{
${ }^{10}$ The CE (Communauté Européenne) mark, is a mandatory conformity marking for certain products sold within the European Economic Area (EEA) since 1985. The CE marking is also found on products sold outside the EEA that are manufactured in, or designed to be sold in, the EEA.

${ }^{11}$ ASTM and SEI are American norms of security that give the possibility to sell products in the USA.
} 
jackets all incorporated curved feminine cuts and were available in a range of colours. This feminisation was even visible in the style of saddles people were buying. "I was the first to use colour in a saddle, and did so specifically for female customers, 20 years ago," said Gaston Mercier, who produced endurance saddles made of red leather. Albert Joël also reveals he has recently added colours in his high-end boot ranges, including red, at the request of his female clientele who are looking for something different from the usual black or brown.

Anthropomorphism has led to the creation of various products designed for the wellbeing of horses according to criteria which come more often from conjecture than from actual knowledge about the needs of horse (numerous carpets, ribbons and blankets in assorted colours). "I want a girth strap for my horse because it suits him well!" proclaimed one young rider and horse owner aged 14 before changing his mind and saying "because it protects the horse when jumping...” (Grefe \& Pickel-Chevalier, 2014).

Feminization, trends, the simultaneous search for a 'community spirit' and differentiation (which is specific to fashion) are leading to an exploitation of different riding activities in response to the needs of individuals looking for social recognition, expressed by a need for consumption that fits with the logic of community or neo-tribal identification (Maffesoli, 2000).

This desire to identify oneself with a world recreated by an activity (Cova, 1996) is widely used by shops in the equine sector with a range of equipment associated with each type of 'equestrian culture' as a sort of code that you belong. Thus, while the idea of 'jumping' suggests an atmosphere of 'competition or innovation' the idea of 'dressage' is more related to classicism and elegance. Endurance favours bright or fluorescent colours coming from more extreme sports (cross-country running, trail-riding, mountain biking), while pony games invented a concept inspired by team sports (bigger and more masculine clothing). Western riding helps to project participants into the myth of the 'American dream' by using cowboy-inspired tack (western saddles and bridles, shirts, jeans, long chaps with tassels, cowboy hats etc). Finally, ethological riding ("natural horsemanship") also allows people to imagine the great U.S. or Australian 'outdoors', but via other methods (casual kit and fashion, an essential ethological halter... and a baseball cap in a 'horse friendly' approach).

e) The professionalization of tools to encourage sales

In the context of a globalised market, and one turned upside-down by very 'aggressive' marketing strategies, word-of-mouth, which was once the rule, is no longer enough. The trade in equine products now fits with more professional market logics, which requires tools which drive forward sales to be, similar to those in other sectors. Marketing has become a key tool for brand development, based on the creation of logos, slogans, and communication policies which may well be aggressive.

Carlos Biclet says, "We chose black and red for our logo so as to be easily identifiable and to stand out in a crowded trade-fair, such as the Salon de Paris." The sponsorship of successful sportspeople has been adopted by many professionals, such as CWD or Wintec, while others prefer to offer trophies (such as Cheval Shop) or decorate the jumps in their corporate colours (L'Eperon, CWD) during well-known competitions, as is the practice in other sports (motor sport, Olympic Games). A new marketing strategy adopted by Butet is aiming to set up a championship called the 'Butet Amateur Tour'. 
It is also becoming important to have people to influence public opinion, such as popular riding champions who are willing to be role models or even big-name stars of the riding world (Kevin Staut, Nicolas Tousaint, Isabel Werth etc.), especially among younger riders. "I am in constant contact with all the champions competing with the CWD team. I send them a text message after each win, regardless of the time difference if they are not in France. It is a fundamental relationship of trust and association between us," explains N. Renard, marketing director for CWD.

Communication policies are also based on extensive use of social networking sites (Facebook, Twitter and forums) which are especially effective with most young riders, 70\% of whom are 18 years old and under (FFE, 2013). They are in the process of developing both physical and psychological personalities (Dolto, 1988) and searching for identity recognition, which leads to mimicry. Websites are also becoming essential at every level of trade in equine products. From the biggest groups to the smallest private companies (AJC Nature, Cavalier du Monde, and independent tack shops) today they all have a website, the purpose of which is twofold:

- e-commerce (online sales) for both large and small businesses (Décathlon, Cheval Shop, Padd, Horsewood, Poney Matériel, AJC Nature, Cavalier du Monde, but also the specialist press such as l'Eperon or Randonner à Cheval).

- communication for specialty brands that are only available via direct sale from the factory or in the consumer's home, particularly in the context of tailor-made products (Albert Joël, Butet, CWD, Gaston Mercier) or through retailers (GPA, Fautras). Their sites, as a showcase for the brand, are nevertheless very 'well-designed' with plenty of detail and interactivity.

The internet can also be used as a tool for diversification, particularly in the case of L'Epéron, which opened a site offering information and interactive feedback which was more attractive for young people: www.cavadeos.com. You have to pay to register (but some information is available free of charge) and allows members access to over 20,000 articles and 3,000 videos related to the horse-riding world. "We do not believe in the death of paper, but paper and digital media can exist side-by-side," declared S. Arderius. The site is very popular and influential with over 100,000 visitors every month.

This professionalization of sales also results in a strengthening of direct and personalized relationships with customers. All the managers interviewed emphasized this requirement in relation to their clients, even when they finally commit to buy on the internet. Carlos Biclet confirms that despite the company having a very dynamic website, keeping and developing the physical shops seems indispensable in a context where the fear of 'fictitious' companies - which do not exist outside the 'internet browser' - is growing. Direct contact with the customer in a shop reassures them, he says. Trade-shows have the same role in allowing sellers to meet and get to know their customers, especially for companies selling mainly via the internet, such as AJC Nature.

"If we miss important shows such as Paris or l'Equita'Lyon our customers think we have gone out of business," says H. Hoefer. New media does not necessarily destroy the direct relationship, but rather transforms it. "It is essential to listen to customers, to be able to 
answer questions quickly by phone or email so as to reassure clients and acquire their loyalty," says C. Lesourd (Cavalier du Monde). In this context, the number of tools to generate loyalty is growing. Copying the techniques of large retailers (Décathlon, Go Sport), specialist companies are now creating their own loyalty cards (Cheval Shop, Padd), sometimes combined with a system of sponsorship (Cheval Shop has introduced a system whereby a client with an internet account earns points for introducing a new customer). This loyalty process works especially well since it uses the logic of belonging and a community spirit which people look for in horse-riding, beyond simply joining a club, as proven by the success of national forums.

As such, the analysis of marketing strategies adopted by companies specializing in the equine trade leads us to observe the adoption of certain trends in the market economy, which is characterized by:

-the development of ranges (from the high-end specialized products via niche products to entry level products),

- adaptability and flexibility,

- differentiation,

- customisation,

- direct relations,

- accessibility.

However, these new strategies are marked by a syncretism with existing equestrian cultures. They do this by adapting to the cultures of the horse world, especially where the desire to maintain traditions remains a leitmotif (Butet, Devoucoux, Albert Joel), even when linked with innovation (CWD, Gaston Mercier, Forestier, Fautras etc.).The ubiquity of equestrian culture can also be seen in the profile of business leaders who, with a few rare exceptions, start out as experienced riders. This quest for a combination of economic and entrepreneurial rationality and a passion for riding seem to characterize the professionalism of those in the industry, which today demands specialized training.

\section{The professionalization of new faces in the equine product market}

Professionalization of actors from both supply and demand also requires new recrutee profiles. Companies are now looking for qualified young people, coming from university courses, who are horse lovers. A passion for horses has become a necessary factor but is no longer enough to be a professional in the equine trade. If today's generation of entrepreneurs is still dominated by those who are self-made men and women, and are often inventors or visionaries (Fautras, GPA Sport, Frédéric Butet, Gaston Mercier, Carlos Biclet etc.), they are now looking for young graduates combining both equestrian and business skills. In this context, many of them are choosing to take on trainees (for between 4 and 6 months) for a trial period and to test them before confirming their contracts. One way this is happening is in the innovation of the Professional Bachelor Degree ${ }^{12}$ in the Marketing of Equine Products, created in 2002 at ESTHUA ${ }^{13}$, which is the only specialist university course in this sector in

\footnotetext{
${ }^{12}$ Such professional degrees are in line with the general EU policy for higher education which a sequence of three years after high school to obtain a Bachelor, then five years to obtain a Masters and then eight years to obtain a PhD. All of this sequence of higher education degrees is also called "Bologna process" and has been adopted by all EU member countries.

${ }^{13}$ Esthua: Faculty of Tourism and Hospitality of the University of Angers.
} 
France. This professional Degree is actually the third specialized in equine economy created in this faculty, after a Bachelor Degree Equestrian Sports and Tourism Management and a Bachelor Degree Riding-Centre Management. In 2006 had been created a fourth Degree at the level of Master: Sport and Tourism Management. The cursus are focus on several sports, but equestrian is a major one. Those creations of equestrian academic Degrees in ESTHUA testify about the needs of qualified staffs in the sector.

The Bachelor Degree of Marketing of Equine Products is well known by professionals who visit each week (1-3 companies per week) to present their businesses and select students for placements after conducting individual interviews. These business leaders come from all over France, but especially from the western part of the country and the Ile de France (Paris area) due to the ease of access to the university.

This recognition among professionals attests to the emergence today of a skills profile that really meets industry needs. "I come back each year to look for future employees from the Professional Degree in the Marketing of Equine Products which corresponds exactly to our expectations. Cheval Shop has expanded thanks to this training," says Carlos Biclet. To further understand this emerging profile, we will now focus primarily on how the training is organized and the criteria for students wanting to join the course.

As with any professional degree in France it is completed in one year, after two years of preparatory university study including internship. During that year it combines lessons on industry knowledge (the history of riding, knowledge of public bodies, equine taxation, equine law, etc.) and specialist lessons on business and communication (negotiation, marketing, communication, accounting, management, business start-ups, website creation and specialist English). Lectures given by professionals, interspersed with company visits, are held each week to allow students to fully discover the extent of the equine market, but also the responsibilities and the character traits of the invited company managers. These guests finish their lectures with individual interviews to identify students for placements.

The training also includes on-the-job experience through two training course a year, at the Salon du Cheval in Paris and in specific companies for a four months period at the end of the academic year.

This combination of theoretical knowledge, regular contact with professionals within the industry and internships, produces graduates with great employability prospects, which contribute to the success of the programme. Its reputation is now confirmed, as evidenced by its use in recruitment across the country. Program leaders have seen, since 2010, how aspiring students make contact with the course co-ordinators as soon as they have finished their highschool diplomas in order to find out what the best training is to guarantee inclusion on the course. While in 2002 many candidates were often young people wishing to join the Degree on Riding-Centre Management but unable to qualify due to a lack of riding skills, we now see a high level of specialization straight out of high-school.

This emerging profile of a future specialist is characterized, like the rest of the sector in France, by a high proportion of women, a number even higher than among horse-riders. $90 \%$ of the students enrolled on the course are in fact girls - compared to $80 \%$ of riders (FFE, 2013). Eighty percent are on their first university course, which means that only $20 \%$ are repeating students. The group is therefore young (around 20 years of age). Unlike the recruitment for students for the Bachelor Degree on Riding-Centre Management, the students 
on the Marketing of Equine Products course do not come from agricultural and rural origins but are mostly from urban backgrounds.

$75 \%$ of them come from marketing courses and their proficiency in English is one of the criteria for joining, as this skill is highly sought-after by professionals. The level of riding skills is less important than their management training, as they are likely to end up running riding-schools, but gallop level 5 (referred to as 'rider' level) is necessary, as is several years of riding experience and a passion for the sport. This feature is essential in the recruiting process because professionals come to the university looking for skills in both riding and business. A good knowledge of the sector is therefore vital.

In a study conducted 6 months after graduation ${ }^{14}$, an in-depth analysis of the employment prospects from the 2011 class-intake revealed ${ }^{15}$ :

- 58\% were in employment (half of these found work directly after finishing the course);

- 27\% were continuing their studies (Business School, Masters in Marketing and

Communication, Masters Tourism and Leisure Sports);

- 10\% were looking for employment;

- 5\% were on a sabbatical year, usually having gone to an English-speaking country to improve their language skills.

We noticed that $73 \%$ of students were employed on permanent contracts. This particularly high rate comes after a six-month internship, serving as a long trial period, allowing the company to commit themselves without taking risks. "After two trade-fairs and six months of internship we know the students and they know us. We therefore know if we can work together," confided C. Biclet. Ninety one percent of these employees are in full-time jobs. Equally, their wages are in line with the average for their degree level: $71 \%$ are paid between 1,000 and 1,600 euros net per month ${ }^{16}$, compared to only $14 \%$ below average and $14 \%$ above average. This situation, which has been ongoing for several years, attests to a sector of industry which is part of the national economy and which, despite the financial crisis which started in 2008, has not seen a significant decrease in the number of new jobs created.

If we map the locations where they are employed (figure 3), the class of 2011 are today working mainly in the western of France even though the students originally come from across the country. This phenomenon illustrates the logic of the professional network they are introduced to during their studies, and which prevails over family logic. While students on the Degree in Riding-Centre Management, who are also recruited from across France, generally return to their hometowns where they have a company waiting or a family link, those on the Marketing of Equine Products course, and who often come from urban areas, create their professional network during their training. They are mostly employed in the western half of France, where the companies recruiting them are based.

\footnotetext{
${ }^{14} 95 \%$ of the students at been graduated.

15 The implementation of the precise inquiries of follow-up of the students is recent in the ESTHUA and are complex because the faculty welcomes 3000 students. The results of 2011 were available in 2013. New results should be available in 2015 to deepen inquiries. But according to the coordinator of the Bachelor Degree who keep an active network with the old students, the statistic of 2011 are representative of the usual employment after graduation of the students.

${ }^{16}$ In 2012, the SMIC (Minimum Legal Salary) in France was of 1118, 36 euro a month. The students are usually paid when they start around 1200/1300 euro a month + profit-sharings.
} 


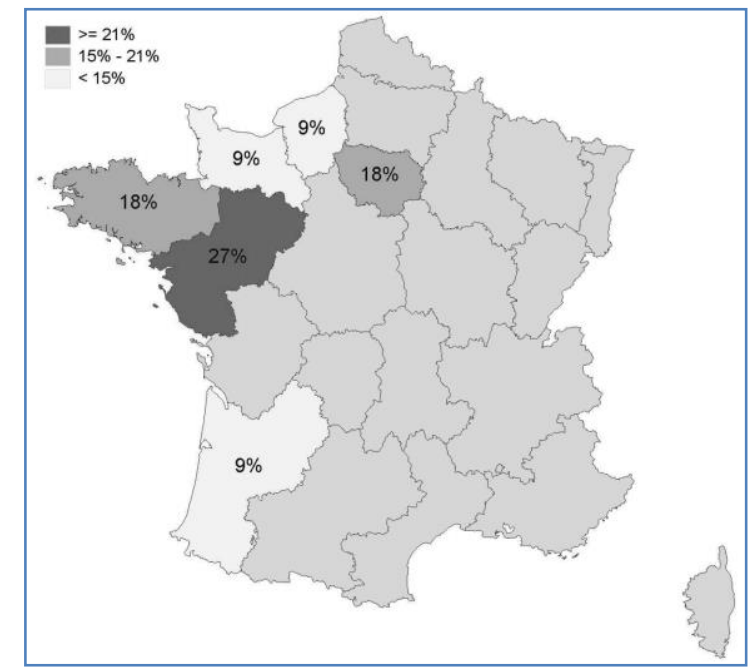

Figure 3. The employability of students from the class of 2011. Design: ESTHUA, University of Angers.

\section{Conclusion}

The trade in equine products has matured by assimilating professional strategies and general market trends for consumer goods where, with the need to compete and stand out, two types of companies coexist: small and medium-sized family companies and large groups. If both are dynamic and successful, the large groups are upsetting the entrepreneurial model of the traditional industry. They oblige the small and medium-sized companies to assimilate the new tendencies of the economy, which are:

-flexibility and diversity;

-accessibility and non-stop communication, through an increased use of modern media (tradefairs, Facebook, web-sites, newsletters etc.);

-innovation;

-safety;

-product value and value for money.

This change has not however taken place by ousting the previous equestrian culture, but by a process of syncretism. The logic of a link, which characterizes the passion for horses - a sense of belonging to a 'community' where social ties prevail, leading to a type of tribalism - 
is a fundamental component of an sector "where everyone knows each other and where we have always known everything," according to many industry insiders. We are witnessing the emergence of a commercial equine economy. This borrows heavily from the global consumer market while maintaining its individuality associated with belonging to a 'cosmos', a community spirit - despite big divisions in the industry - and a willingness to preserve traditions. Innovation is important but it doesn't sweep away the old equestrian culture. It modernizes and reworks it, rather than completely reinventing it.

This evolution nevertheless requires changes and heavy investment by small and medium-sized companies in a very competitive environment, or they risk disappearing from a dynamic market (but one limited to less than $4 \%$ of the French population), and one which is restructuring itself and producing transformed and diversified profiles. The quality and ethical positioning ('made in France') allows the high-end market to resist moving production overseas and instead invest in high technology, innovation and ethics ${ }^{17}$ But the balance of forces is difficult to maintain; the relocation of production, especially for 'fashion' products where design is more important than quality, is widespread. The weakness of small and medium-sized companies is exacerbated by the good price/quality ratio of groups, such as Decathlon which specializes in innovations, and this is constantly increasing.

These developments require increased professionalization, including passion, but not only this. Beyond the generational divide - old school/new school - new job profiles are emerging. This is defined by new business skills and including the now very well-understood precepts of marketing. The analysis of professional training programmes (Marketing of Equine Products and Riding-Centre Management) which have been running for the last 10 years has allowed us to witness the emergence of a new profile of professionalism in the equine business. Breaking away from the previous logic of family and rural ties, these new employees define themselves, just like their customers, as young urban dwellers who love riding in a leisure context and do not necessarily have links to the traditional equine industry. They have the distinction of being associated with a logic of neo-tribalism formed around riding, while being able to stand back and adapt professionally given the diversity of cultures present in horse-riding.

The equine trade is therefore well ingrained in the global market for consumer goods while retaining its own peculiarities. Under pressure, but also stimulated by the requirements of a changing and diversified client group, it has resulted in a totally new equine economy leading to a metamarket and encouraging the confirmation of new job profiles. These are characterized by a dual insider/outsider relationship to the market and equestrian 'tribalism'.

\section{References}

Bessy, O. and M. Mouton, 2004. Du plein air au sport de nature. Nouvelles pratiques, nouveaux enjeux. In: Cahier Espaces 81 - Sports de nature, Évolutions de l'offre et de la demande, Editions Espaces tourisme \& loisirs, Mai 2004, 17p.

Chevalier, V., 1998. Pratiques culturelles et carrières d'amateurs : le cas des parcours de cavaliers dans les clubs d'équitation. Sociétés contemporaines, 1998/1, 29, 27-41.

\footnotetext{
${ }^{17}$ For example the companies Butet and Devaucoux have purchased a laser cutting tool giving better profitability when preparing leather parts, saving time and reducing waste off-cuts of material.
} 
Chevalier, V. and B. Dussart, 2002. De l'amateur au professionnel : le cas des pratiquants de l'équitation. L'Année sociologique 2/ 2002, 52, 459-476.

Corbin, A., 2001. L'avènement des loisirs, 1850-1960, Champs-Flammarion, Paris.

Cova, B., 1996. The postmodern explained to managers: implications for marketing. Business Horizon, 21 November 1996, 21.

Defrance, J., 2011. Sociologie du sport. La découverte, Paris, France.

Digard, J.P., 2004. Une histoire du cheval. Actes Sud, Paris, France.

Digard, J.P., 2009. Le cheval, un animal domestique au destin exceptionnel. In: Arts Equestres, Revue 303 Arts, recherche et créations, 2009, 12-19.

Dumazedier, J., 1962. Vers une civilisation du loisir? Ed. Seuil, Paris, France.

FFE, 2012. Dossier fidélité des licenciés 2012, CE Le Paddock, www./ffe/sif/.

Franchet d'Espèrey, P. (ed.), 2011. L'équitation française, Le Cadre Noir de Saumur et les écoles européennes, Doctrines, traditions et perspectives, Lavauzelle, France.

Grefe, G. and S. Pickel-Chevalier, 2014. De la transformation des établissements équestres en France : une offre fragilisée ou favorisée par l'évolution sociétale de l'équitation ? In: Pickel-Chevalier, S. and Evans, R., Cheval, tourisme et sociétés / Horse, tourism and societies, Editions Spéciales Monde du Tourisme, Paris, France -forthcoming.

IFCE, 2011. Panorama économique de la filière équine. Les haras nationaux, Haras du Pin, France.

Institut National de la Statistique et des Etudes Economiques (INSEE), 2013. http://www.insee.fr/fr/regions/.

Jez, C., 2013. The foresight approach. Advances in Animal Biosciences 4(2), 52-53.

Kotler, P. and K. Lane Keller, 2009. A Framework for Marketing Management. Fourth Edition.

Lambin, J-J. and C. de Moerloose, 2012. Marketing stratégique et opérationnel du marketing à l'orientation de marché. 8e édition, Edition Dunod.

Maffesoli, M, 2000. Le temps des tribus: Le déclin de l'individualisme dans les sociétés postmodernes. Essai, Poche, Paris, France.

MIT, 2005. Tourisme 2. Les moments de lieux. Belin, coll «Mappemonde », Paris.

Pickel-Chevalier, S., 2015. Can equestrian tourisme be a solution for sustainable tourism development in France? Loisir et sociétés/Society and Leisure - forthcoming.

Pickel-Chevalier, S. and G. Grefe, 2014. Le cheval réinventé par la société des loisirs en Occident : une mythologie révolutionnée ? (XVIII-XXIe). In: Pickel-Chevalier S. et Evans R. (ed), Cheval, tourisme et sociétés du Monde/ Horse, tourism and World societies, Editions Spéciales Monde du Tourisme, Paris, France - forthcoming.

Roche, D., 2008. La culture équestre de l'Occident XVI-XIXe s. Editions Fayard, Paris, France.

Terret, T., 2007. Histoire du sport. PUF, collection Que sais-je ?, Paris, France.

Tourre-Malen, C., 2006. Femmes à cheval. La féminisation des sports et des loisirs équestres : une avancée ? Belin, Paris, France.

Tourre-Malen, C., 2009. Évolution des Activités Équestres et Changement Social en France à partir des années 1960. In: Le Mouvement Social 229, La Découverte, 41-59.

http://www.ffe.com/journaliste/Publications/Statistiques, 30 March 2015. 